\title{
Effect of Infestation of Alabama argillacea (Lepidoptera: Noctuidae) at Different Ages of Cotton Plants in Yield
}

\author{
Marcos Doniseti Michelotto', Jacob Crosariol Netto², José Fernando Grigolli3, \\ Antonio Carlos Busoli ${ }^{2}$, Willians Cesar Carrega ${ }^{4}$, Everton Luis Finoto', \\ Juliana Altafin Galli ${ }^{*}$ \\ ${ }^{1}$ Apta North Centre, Pindorama, Brazil \\ ${ }^{2}$ Department of Crop Protection, FCAV/Unesp, Jaboticabal, Brazil \\ ${ }^{3} \mathrm{MS}$ Foundation, Maracaju-MS, Brazil \\ ${ }^{4}$ Department of Vegetal Production, FCAV/Unesp, Jaboticabal, Brazil \\ Email: michelotto@apta.sp.gov.br, jacob netto@hotmail.com, jose fernando ig@yahoo.com.br, \\ acbusoli@fcav.unesp.br, willianscesar@hotmail.com, evertonfinoto@apta.sp.gov.br, \\ julianagalli@apta.sp.gov.br
}

Received 31 January 2014; revised 4 April 2014; accepted 19 April 2014

Copyright (C) 2014 by authors and Scientific Research Publishing Inc.

This work is licensed under the Creative Commons Attribution International License (CC BY). http://creativecommons.org/licenses/by/4.0/

(c) (i) Open Access

\section{Abstract}

The cotton leafworm is an important defoliating pest of cotton in Brazil, and occurs in all regions where the crop is cultivated. The purpose of this study was to evaluate the effect of larval densities of $A$. argillacea after different infestation periods on the yield components of four cotton cultivars. The experiment was carried out in Pindorama, SP, Brazil, in the 2008/2009 growing season. The cultivars IAC-25, DeltaOPAL, Fibermax 966 and Fibermax 993 were artificially infested with $A$. argillacea larvae at three times (30, 60 and 90 DAE) and four densities $(0,2,4$, and 6 larvae per plant). The average boll weight (g), fiber percentage (\%), 100-seed weight (g) and yield (kg.ha-1) were evaluated. With increasing infestation density of $\boldsymbol{A}$. argillacea, the cotton yield of the cultivars decreased. The presence of larvae significantly reduced the weight of 100 seeds of cultivar Fibermax 966. Initial infestations reduced the boll weight of IAC-25 and DeltaOPAL, while cultivars Fibermax 966 and Fibermax 993 were most affected by late infestations. Early infestation compromised fiber percentage of cultivar DeltaOPAL and late infestations were most harmful to cultivar Fibermax 966. Early A. argillacea infestation reduced the yield of DeltaOPAL, while infestations 60 DAE caused the most damage to IAC-25, and the other cultivars were not affected by the moment of infestation.

\footnotetext{
${ }^{*}$ Corresponding author.
}

How to cite this paper: Michelotto, M.D., et al. (2014) Effect of Infestation of Alabama argillacea (Lepidoptera: Noctuidae) at Different Ages of Cotton Plants in Yield. American Journal of Plant Sciences, 5, 1441-1448. 


\section{Keywords}

\section{Gossypium hirsutum, Cotton Leafworm, Cultivars, Biotic Stress}

\section{Introduction}

Cotton industry is a socially and economic relevant activity in the agricultural scenario of Brazil. The centralwest region is the country's leading producer, with about $62.7 \%$ of the cotton production in Brazil in the 2012/ 2013 growing season [1].

The cotton leafworm, Alabama argillacea (Hübner, 1818) (Lepidoptera: Noctuidae), is the important defoliating pest of the crop, causing great yield losses if not controlled properly [2] [3]. This pest causes great damage by the high intensity of plant defoliation to meet the larval food demand. The pest can occur from the initial crop development stages to maturation, in all cotton-cultivating regions of Brazil [2] [4] and often reaches the threshold level that makes control measures necessary [5]. According to the researchers [6] [7], the plants are not resistant to high losses of leaf area in the first 45 days of development.

The cotton leafworm consumes a cotton leaf area of $88 \mathrm{~cm}^{2}$ of all instars [8], while other author [9] found that at a constant temperature of $27.5^{\circ} \mathrm{C}$, the average larval consumption was $117.95 \mathrm{~cm}^{2}$, and that the last instar larvae consumed approximately $73 \%$ of the total.

Development of efficient strategies to control A. argillacea requires the understanding of its biological relationship with the host plant. Therefore, an important component is to understand the host's susceptibility to the pest [10].

In view of the high destructive capacity of cotton leafworm and lack of information about the impact of infestation at different times and levels on novel cotton cultivars, the purpose of this study was to evaluate the effect of different larval densities after different infestation periods on the yield components of four cotton cultivars.

\section{Material and Methods}

The experiment was conducted on an experimental field and in the laboratory of Entomology of the Agência Paulista de Tecnologia dos Agronegócios (APTA), Polo Regional do Centro Norte, in Pindorama, São Paulo, Brazil, (21 $11^{\circ} 9^{\prime \prime S}$ and $\left.48^{\circ} 4^{\prime} 25^{\prime \prime} \mathrm{W}\right)$. The experiment was arranged in a randomized factorial block design with 48 treatments ( 4 cultivars $\times 4$ larval densities per plant $\times 3$ infestation periods), with 4 replications.

\subsection{Rearing A. argillacea}

Larvae of A. argillacea were raised artificially by the methodology proposed by workers [11]. Pupae of A. argillacea were collected from cotton plantations of the APTA in Pindorama, SP, sexed and transferred to Petri dishes (diameter $9 \mathrm{~cm}$, height $1.5 \mathrm{~cm}$ ), and placed in PVC cages (height $21.5 \mathrm{~cm}$, diameter $20 \mathrm{~cm}$ ) lined with printing paper as substrate for oviposition until adult emergence. The top of the cage was covered with voile and the base set on a plastic dish lined with paper towel. Sponges (thickness $0.5 \mathrm{~cm}$, diameter $5 \mathrm{~cm}$ ) were placed in the cage, soaked with a $50 \%$ honey solution, to feed the adults. During oviposition, the paper and voile containing eggs were transferred daily to cages similar to those used for the adults. After two days, this egg-containing material was distributed on cotton leaves, with the stem inserted in water, in glasses sealed with a cotton wool ball. The newly-hatched larvae were fed with leaves of cotton cultivar Coodetec 407, collected in a greenhouse and washed in tap water and in a $2 \%$ sodium hypochlorite solution for $2 \mathrm{~min}$, followed by four washes in tap water.

\subsection{Crop Management}

The soil was tilled and limed as recommended for the crop. The cotton cultivars DeltaOPAL, IAC-20, Fibermax 966, and Fibermax 993 were sown mechanically on 15 December 2008, for a final germination of 12 plants per meter. Each plot consisted of three 4-m long rows spaced 0.9 meters apart. Five plants of each cultivar per replication were infested 30, 60 and 90 DAE with 0, 2, 4, and 6 third-instar larvae (length $15 \mathrm{~mm}$, mass $60 \pm 10$ $\mathrm{mg})$. After infestation, the plants were protected by rectangular cages consisting of metal frames $(0.8 \times 1.2 \times 1.0$ $\mathrm{m})(\mathrm{W} \times \mathrm{H} \times \mathrm{D})$, completely covered by voile, corresponding to the size of each plot. Insecticide was not needed for pest control. To prevent excessive growth of cotton plants and to facilitate the management practices, a plant 
growth regulator (mepiquat chloride) was applied twice (50 and 70 DAE, respectively, at 300 and 500 mlp.c. $\mathrm{ha}^{-1}$ ) to obtain a final plant height of $1.10-1.20 \mathrm{~m}$, as currently recommended for mechanical harvesting [12].

\subsection{Parameters Evaluated}

At the end of the cycle, when all bolls had opened, the plants in the cages were harvested and the following parameters assessed: average boll weight (g), lint percentage (\%), 100-seed weight (g), and average yield per cultivar $\left(\mathrm{kg} \cdot \mathrm{ha}^{-1}\right)$.To determine the 100 -seed weight and fiber content, samples of all plots were sent to the laboratory for Fiber Technology of the Grain and Fiber Center of the Agronomic Institute of Campinas (IAC).

\subsection{Data Analysis}

Data were subjected to analysis of variance and treatment means were compared by Tukey's test at 5\% probability. The data were not transformed for statistical analyses.

\section{Results}

Significant differences were observed in the parameters average boll weight, lint percentage, 100-seed weight and cotton yield of the cultivars evaluated (Table 1).

The average boll weight (5.82 and 5.50 g respectively) and average yield (2344.0 and $2350.0 \mathrm{~kg} \cdot \mathrm{ha}^{-1}$, respectively) of the cultivars DeltaOPAL and Fibermax 993 were highest while the cultivars Fibermax 966 and Fibermax 993 had the highest lint percentage (38.94\% and 39.63\%, respectively) and IAC-25 the highest 100 -seed weight (13.90 g) (Table 1). The higher infestation density of A. argillacea larvae, the lower average boll weight (5.72 $\mathrm{g}$ for 0 larva per plant to $5.25 \mathrm{~g}$ for 6 larvae per plant) and the lower yield of the cultivars $\left(2753.0 \mathrm{~kg} \cdot \mathrm{ha}^{-1}\right.$ for 0 larva per plant to $1566.6 \mathrm{~kg} \cdot \mathrm{ha}^{-1}$ for 6 larvae per plant), whereas lint percentage and 100-seed weight were not influenced by the larval density (Table 1). The time of larval infestations was significantly related with yield, and inoculations 30 DAE and 60 DAE reduced the mean cultivaryield more (2075.8 and $2038.3 \mathrm{~kg} \cdot \mathrm{ha}^{-1}$, respectively) than late inoculations 90 DAE $\left(2273.0 \mathrm{~kg} \cdot \mathrm{ha}^{-1}\right)$ (Table 1).

The partition analysis of the cotton cultivars and infestation period for the parameter average boll weight indicated that all cultivars were influenced by the time of infestation, so that the average boll weight was lowest when infestation occurred 60 DAE on IAC-25 (4.75 g), 30 DAE (5.18 g) on cultivar DeltaOPAL, and 90 DAE (4.85 and 4.99 g, respectively) on cultivars Fibermax 966 and Fibermax 993 (Figure 1).

Table 1. Mean ( \pm SE) boll weight (g), lint percentage (\%), 100-seed weight (g) and yield $\left(\mathrm{kg} \cdot \mathrm{ha}^{-1}\right)$ in cotton cultivars infested with different densities of Alabama argillacea larvae at different times after plant emergence.

\begin{tabular}{|c|c|c|c|c|}
\hline Cultivars (C) & Boll weight (g) & Lint percentage (\%) & 100-seed weight (g) & Yield $\left(\mathrm{kg} \cdot \mathrm{ha}^{-1}\right)$ \\
\hline IAC-25 & $5.1 \pm 1.02 b$ & $37.0 \pm 3.38 c$ & $13.9 \pm 1.58 \mathrm{a}$ & $1953.4 \pm 990.94 b$ \\
\hline DeltaOPAL & $5.8 \pm 0.82 \mathrm{a}$ & $37.9 \pm 2.78 b c$ & $12.9 \pm 1.69 b$ & $2344.0 \pm 749.79 a$ \\
\hline Fibermax 966 & $5.4 \pm 0.83 b$ & $38.9 \pm 3.35 a b$ & $12.3 \pm 1.56 \mathrm{bc}$ & $1868.7 \pm 580.81 b$ \\
\hline Fibermax 993 & $5.5 \pm 0.59 \mathrm{ab}$ & $39.6 \pm 5.27 \mathrm{a}$ & $12.0 \pm 1.19 c$ & $2350.0 \pm 410.33 a$ \\
\hline F-Test & $7.04^{* *}$ & $8.53^{* *}$ & $20.38^{* *}$ & $13.18^{* *}$ \\
\hline \multicolumn{5}{|l|}{ Larvae (L) } \\
\hline 0 & $5.7 \pm 0.77 a$ & $37.6 \pm 5.74 a$ & $13.2 \pm 1.64 \mathrm{a}$ & $2753.3 \pm 625.43 a$ \\
\hline 2 & $5.4 \pm 0.73 a b$ & $38.8 \pm 2.43 a$ & $12.7 \pm 1.62 \mathrm{a}$ & $2196.9 \pm 633.19 b$ \\
\hline 4 & $5.4 \pm 0.82 \mathrm{ab}$ & $38.6 \pm 3.28 a$ & $12.7 \pm 1.54 \mathrm{a}$ & $1999.4 \pm 669.11 b$ \\
\hline 6 & $5.3 \pm 1.04 b$ & $38.5 \pm 2.93 a$ & $12.6 \pm 1.82 \mathrm{a}$ & $1566.6 \pm 514.75 c$ \\
\hline F-Test & $3.31^{*}$ & $1.89^{\mathrm{ns}}$ & $2.23^{\mathrm{ns}}$ & $49.50^{* *}$ \\
\hline \multicolumn{5}{|l|}{ Plant Age (A) } \\
\hline $30 \mathrm{DAE}$ & $5.5 \pm 0.82 a$ & $38.3 \pm 2.82 \mathrm{a}$ & $12.8 \pm 1.55 a$ & $2075.8 \pm 755.61 \mathrm{ab}$ \\
\hline $60 \mathrm{DAE}$ & $5.5 \pm 0.83 a$ & $38.6 \pm 5.26 a$ & $12.8 \pm 1.72 \mathrm{a}$ & $2038.3 \pm 725.83 b$ \\
\hline $90 \mathrm{DAE}$ & $5.3 \pm 0.93 a$ & $38.2 \pm 3.13 a$ & $12.7 \pm 1.75 \mathrm{a}$ & $2273.0 \pm 739.41 a$ \\
\hline F-Test & $1.05^{\mathrm{ns}}$ & $0.26^{\mathrm{ns}}$ & $0.86^{\mathrm{ns}}$ & $4.33^{*}$ \\
\hline $\mathrm{C} \times \mathrm{L}$ & $1.19^{\mathrm{ns}}$ & $0.85^{\mathrm{ns}}$ & $2.09^{*}$ & $2.48^{*}$ \\
\hline $\mathrm{C} \times \mathrm{A}$ & $8.00^{*}$ & $4.65^{* *}$ & $6.48^{* *}$ & $4.65^{* *}$ \\
\hline $\mathrm{L} \times \mathrm{A}$ & $1.06^{\mathrm{ns}}$ & $0.85^{\mathrm{ns}}$ & $0.48^{\mathrm{ns}}$ & $1.71^{\mathrm{ns}}$ \\
\hline
\end{tabular}

Means followed by different letters in the column differ by Tukey’s $(\mathrm{p} \leq 0.05)$. ${ }^{\mathrm{ns}}$ Not significant; ${ }^{*} \mathrm{p}<0.05,{ }^{* *} \mathrm{p}<0.01$. 
(a)
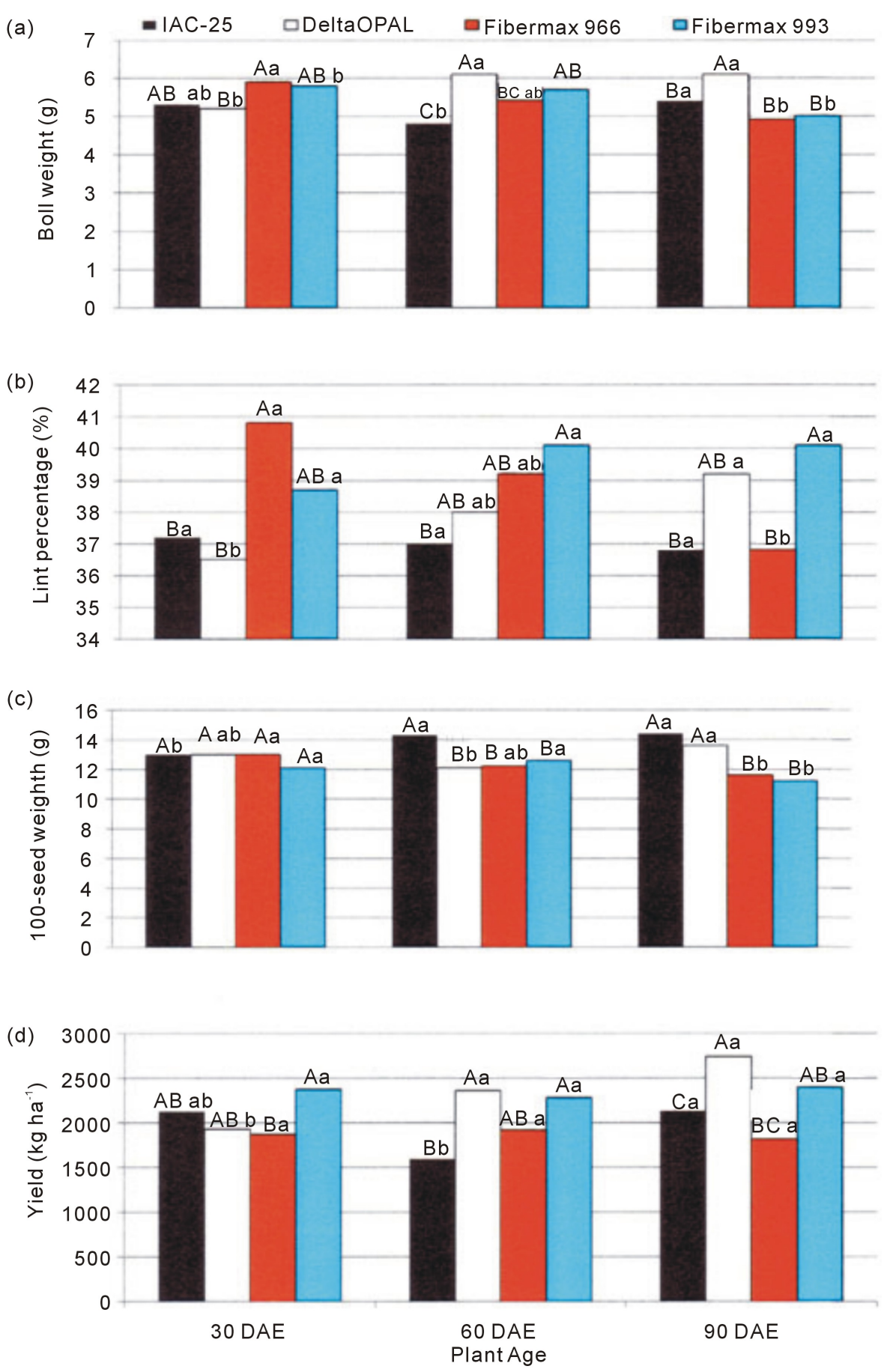

Figure 1. Mean values of the unfolding analysis of the significant interactions for (a) boll weight (g), (b) lint percentage (\%), (c) 100-seed weight (g) and (d) yield (kg·ha ${ }^{-1}$ )in cotton cultivars infested withAlabama argillacealarvae at different times after plant emergence.Bars followed by the same lowercase (comparisons for cultivars across plant age) or capital (comparisons for cultivars within the same plant age) letters do not differ significantly by Tukey's ( $p>0.05)$.

The boll development of cultivar DeltaOPAL was most affected by initial infestation (30 DAE), while for IAC-25 infestations in the middle of the cycle (60 DAE) were most damaging, and late infestations (90DAE) were most harmful to boll development of IAC-25, Fibermax 966, and Fibermax 993 (Figure 1). 
The larva infestation period did not influence the lint percentage of IAC-25 and Fibermax 993; infestations 30 DAE were more harmful to cultivar DeltaOPAL than later ones, whereas late infestations (90 DAE) affected cultivar Fibermax 966 most (Figure 1).

Early infestations (30 DAE) were more damaging to lint percentage of the cultivars IAC-25 (37.24\%) and DeltaOPAL (36.49\%) than of Fibermax 966 (40.83\%) and Fibermax 993 (38.81\%). Infestations of A. argillacea 60 DAE were more harmful to IAC-25 (36.98\%), followed by DeltaOPAL (37.98\%) and Fibermax 966 (39.21\%), while Fibermax 993 was least affected (40.08\%). At the end of the crop cycle, the occurrence of $A$. argillacea was more detrimental to IAC-25 (36.83\%) and Fibermax 966 (36.78\%), followed by DeltaOPAL (39.18\%), and Fibermax 993 (40.12\%) (Figure 1).

The interaction between cultivars and larval density was significant for the parameters 100-seed weight and yield among cultivars and infestation period on the parameters average boll weight, lint percentage, 100-seed weight, and cultivar yield. No significant interaction was detected between infestation period and density (Table 1).

The partition analysis of cotton cultivars and larval density indicated that only 100-seed weight of cultivar Fibermax 966 was reduced in the presence of larvae, where a reduction of 100-seed weight was observed in the presence of larvae (Figure 2). With regard to the performance of cultivars at each larval density, the average 100-seed weight of Fibermax 993 without larva infestation was lower than of the other cultivars, while cultivar Fibermax 966 had lowest average 100-seed weight with two and four A. argillacea larvae per plant and DeltaOPAL, Fibermax 966 and Fibermax 993 with six larvae per plant (Figure 2).

The partition analysis of cotton cultivars and A. argillacea infestation period in relation to 100 -seed weight indicated that IAC-25 was more damaged by initial infestations (30 DAE), the cultivar DeltaOPAL was more compromised when infested 60 DAE and cultivars Fibermax 966 and Fibermax 993 were most affected by late infestation (90 DAE), which reduced the 100-seed weight significantly (Figure 1).

The weight of 100 seeds did not vary significantly among cultivars after infestation 30 DAE; 60 DAE, the
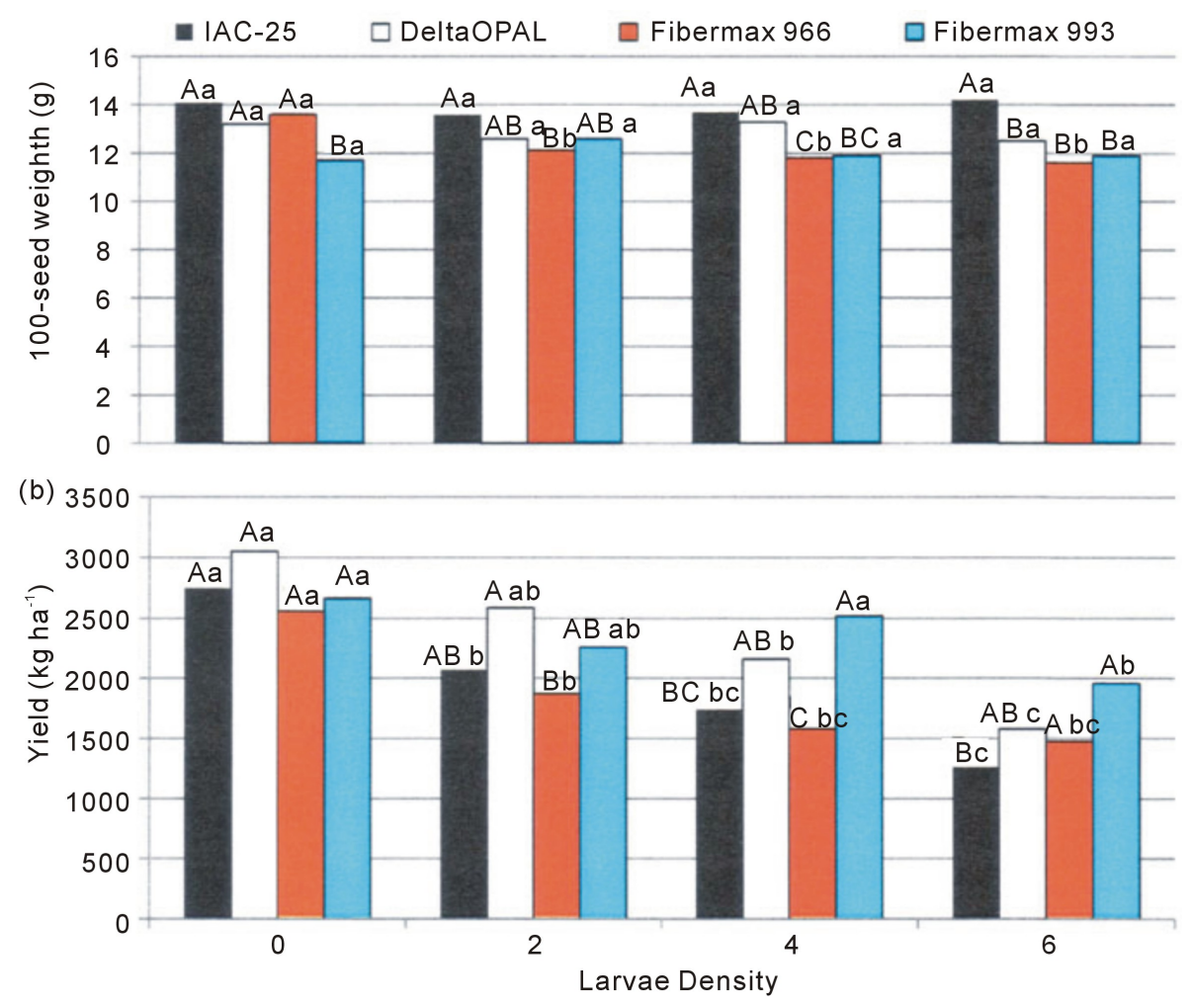

Figure 2. Mean values of the unfolding analysis of the significant interactions for (a) 100seed weight (g), and (b) yield $\left(\mathrm{kg} \cdot \mathrm{ha}^{-1}\right)$ in cotton cultivars infested with different densities of Alabama argillacea larvae. Bars followed by the same lowercase (comparisons for cultivars across larvae density) or capital (comparisons for cultivars within the same larvae density) letters do not differ significantly by Tukey's test $(\mathrm{p}>0.05)$. 
100-seed weight of cultivar IAC-25 was the highest, and 90 DAE of IAC-25 and DeltaOPAL (Figure 1).

The partition analysis of cotton cultivars and larval density indicated that an increased number of A. argillacea larvae per plant significantly reduced the yield of all cultivars, so that 6 larvae per plant resulted in lower yield of IAC-25, DeltaOPAL, Fibermax 966 and Fibermax 993 (1255.3, 1578.3, 1474.3, and $1958.4 \mathrm{~kg} \cdot \mathrm{ha}^{-1}$ respectively) (Figure 2).

The yield of plants without A. argillacea larvae was the same, while DeltaOPAL had the highest yield with two larvae, and Fibermax 993 had the highest yield when infested with four and six larvae per plant (Figure 2).

\section{Discussion}

The results showed that the larval density infestation influenced the boll weight and cultivar yield, while time of infestation influenced yield. The partition analysis of cotton cultivars and larvae infestation period for yield indicated that IAC-25 was more impaired by infestations 60 DAE and DeltaOPAL 30 DAE, while infestations at different phenological stages of the plants did not affect the yield of Fibermax 966 and Fibermax 993 (Figure 1). Silva et al. [13] to simulate the defoliation at different phenological stages of cotton, verified that defoliation done in the early fruiting (opening of the first flower) resulting in major reductions in productivity.

For the parameter weight of 100 seeds, the partition analysis of the cotton cultivars and infestation period showed that the 100-seeds weight of cultivar IAC-25 was highest at 60 and 90 DAE, suggest that plantations of cultivars DeltaOPAL, Fibermax 966 and Fibermax 993 are more prejudiced than of IAC-25. This scenario is more severe in seed production fields, where a reduction in seed weight is likely to affect the seed quality.

The partition analysis of cotton cultivars and larval density indicates that at a low infestation (up to 2 larvae per plant), DeltaOPAL can overcome the pest attack better than the other cultivars, while at high infestations (4 - 6 larvae per plant), cultivar Fibermax 993 supports A. argillacea infestation better than the other cultivars.

The reduction in cotton yield by A. argillacea was evaluated by other researchers [14], who found that the reduction in cotton yield was a consequence of the reduced boll weight or number. According to [15], this can be explained by the ease with which assimilates reach these plant parts. Moreover, the leaves of the main stem are the most important because they nourish branch growth, being one of the main factors contributing to cotton yield [16].

The consumption of the primary leaves of cotton plants by A. argillacea (early infestation) was more damaging because these leaves are grown first by the plant and account for over $80 \%$ of the cotton yield [17]. In addition, vegetative leaves live longer and have a greater leaf area than fruit leaves [18], and are responsible for vegetative production and growth of the cotton plant [3]. The development of cotton plants is compromised by the removal of leaves from the main stem [19], which drastically reduces the yield, number of fruit branches and plant height [20].

\section{Conclusion}

The result on this paper shows that higher infestation densities of A. argillacea increase yield reduction and the presence of larvae reduces the 100-seed weight of cultivar Fibermax 966. Initial infestations affect the boll weight of IAC-25 and DeltaOPAL, whereas the cultivars Fibermax 966 and Fibermax 993 are most affected by late infestations. Initial infestations of A. argillacea affect the fiber percentage of cultivar DeltaOPAL and late infestations are more harmful to Fibermax 966. Initial infestations of A. argillacea reduce the yield of cultivar DeltaOPAL, while infestations 60 DAE cause the most damage to IAC-25 and the time of infestation does not influence the other cultivars.

\section{Acknowledgements}

We thank the Fundação de Amparo a Pesquisa do Estado de São Paulo (FAPESP), for financial support.

\section{References}

[1] Conab. Companhia Nacional do Abastecimento. National Supply Company “Acompanhamento da safra brasileira: Grãos, Safra 2012/2013” (2013) Monitoring Brazilian harvest: Grains, Harvest 2012/2013. http://www.conab.gov.br/OlalaCMS/uploads/arquivos/13 $08 \quad 09 \quad 1043 \quad 44$ boletim portuges agosto 2013 port.pdf

[2] Quirino, E.S. and Soares, J.J. (2001) Efeito do ataque de Alabama argillacea no crescimento vegetativo e sua relação 
com a fenologia do algodoeiro (Effect of Alabama argillacea Attack on Vegetative Growth and Its Relationship with Cotton Phenology). Pesquisa Agropecuária Brasileira, 36, 1005-1010. http://www.scielo.br/pdf/pab/v36n8/6457.pdf http://dx.doi.org/10.1590/S0100-204X2001000800001

[3] Jácome, A.G., Soares, J.J., Oliveira, R.H., Campos, K.M.F., Macedo, E.S. and Gonçalves, A.C.A. (2003) Importância das folhas da haste principal e das folhas do ramo no crescimento e produtividade do algodoeiro herbáceo CNPA 7H (The Importance of the Main Stem Leaves and Fruitfull Branches in the Vegetative Growth Development and Production of Cultivar CNPA 7H). Acta Scientiarum Agronomy, 25, 209-213. http://dx.doi.org/10.4025/actasciagron.v25i1.2673

[4] Soares, J.J. and Silva, M.S. (2003) Efeito da época de plantio na produção e na ocorrência de pragas em culturas do algodoeiro (Gossypium hirsutum) (Effect of Planting Date on the Production and the Ocurrence of Pests on Cotton (Gossypium hirsutum)). Arquivos do Instituto Biológico, 70, 295-302.

http://www.biologico.sp.gov.br/docs/arq/V70_3/soares.PDF

[5] Domiciano, N.L. and Santos, W.J. (1994) Momento adequado para aplicação de inseticida no controle do curuquerêdo-algodoeiro (Timing Insecticide Applications to Control the Cotton Leafworm). Pesquisa Agropecuária Brasileira, 29, 7-11. http://seer.sct.embrapa.br/index.php/pab/article/view/4021/1312

[6] Cavalcanti, R.D. (1977) O combate ao curuquerê do algodoeiro (The Fight against the Cotton Leafworm). Boletim Fitossanitário, 239, 1-2.

[7] Bleicher, E., Silva, A.L., Santos, W.J., Gravena, S., Nakano, O. and Ferreira, L. (1983) Conheça os insetos da sua lavoura de algodão (Meet the Insects of Cotton Crop). Embrapa, Campina Grande.

[8] Alvarez, R.J.A. and Sanchez, G.C. (1982) Alabama argillacea (Hüebner) ciclo de vida y consumo foliar (Alabama argillacea (Huebner) Cycle Life and Foliar Consumption). Revista Colombiana de Entomología, 8, 34-38.

[9] Johnson, S.J. (1984) Larval Development, Consumption, and Feeding Behavior of the Cotton Leaf Worm, Alabama argillacea (Hüebner)). Southwestern Entomologist, 9, 1-6.

[10] Nascimento, A.R.B., Ramalho, F.S., Azeredo, T.L., Fernandes, F.S., Nascimento Júnior, J.L., Silva, C.A.D. and Malaquias, J.B. (2011) Feeding and Life History of Alabama argillacea (Lepidoptera: Noctuidae) on Cotton Cultivars Producing Colored Fibers). Annals of the Entomological Society of America, 104, 613-619. http://dx.doi.org/10.1603/AN10195

[11] Santos, T.M. and Boiça Júnior, A.L. (2001) Resistência de genótipos de algodoeiro (Gossypium hirsutum L.) e Alabama argillacea (Hüebner) (Lepidoptera: Noctuidae) (Resistance of Cotton Genotypes (Gossypium hirsutum L.) to Alabama argilacea (Hübner) (Lepidoptera: Noctuidae)). Neotropical Entomology, 30, 297-303.

http://www.scielo.br/pdf/ne/v30n2/a14v30n2.pdf http://dx.doi.org/10.1590/S1519-566X2001000200014

[12] Busoli, A.C., Soares, J.J. and Lara, F.M. (1984) O bicudo do algodoeiro e seu manejo (The Cotton Boll Weevil and Its Management). Funep, Jaboticabal.

[13] da Silva, A.M., Degrande, P.E., Suekane, R., Fernandes, M.G. and Zeviani, W.M. (2012) Impacto de diferentes níveis de desfolha artificial nos estádios fenológicos do algodoeiro (Impact of Different Levels of Artificial Defoliation in Cotton Phenology). Revista de Ciências Agrárias, 35, 63-172.

http://www.scielo.gpeari.mctes.pt/scielo.php?script=sci_arttext\&pid=S0871-018X2012000100016\&lng=pt\&nrm=iso\& $\underline{\text { tlng=pt }}$

[14] Helman, S.A., Beltran, R.E., Garay, F. and Raña, E. (2011) Efecto de las poblaciones de Alabama argillacea (Hübner) (Lepidoptera: Noctuidae) en cultivos de algodón a dos distanciamentos (Effect of the Populations of Alabama argillacea (Hübner) (Lepidoptera: Noctuidae) on Cotton Crop at Two Sowing Distances). Neotropical Entomology, 40, 251-257. http://www.scielo.br/pdf/ne/v40n2/15.pdf http://dx.doi.org/10.1590/S1519-566X2011000200015

[15] Beltrão, N.E.M., Azevedo, D.M.P., Vieira, D.J., Nóbrega, L.B., Quiroga, V.P., Santos, J.W., Queiroz, J.C. and Souza, J.E.G. (1993) Observações morfológicas e agronômicas em algodoeiro arbóreo precoce. II. Frutograma de plantas da cultivar CNPA $5 \mathrm{M}$ de $1^{\circ}$ e $2^{\circ}$ anos de ciclo (Morphological and Agronomic Observations in Arboreal Early Cotton). Embrapa, Campina Grande.

[16] Mauney, J.R. (1986) Vegetative Growth and Development of Fruiting. In: Mauney, J.R. and Stewart, J.M., Eds., Cotton physiology, The Cotton Foundation, Memphis, 11-28.

[17] Soares, J.J., Lara, F.M., Silva, C.A.D., Almeida, R.P. and Wanderley, D.S. (1999) Influência da posição do fruto na planta sobre a produção do algodoeiro (Influence of Fruiting Position on Cotton Production). Pesquisa Agropecuária Brasileira, 34, 755-759. http://www.scielo.br/pdf/pab/v34n5/8420.pdf http://dx.doi.org/10.1590/S0100-204X1999000500005

[18] Hearn, A.B. and Constable, G.A. (1984) Cotton. In: Goldsworth, P.R. and Fisher, N.M., Eds., The Physiology of Tropical Field Crops, John Wiley, New York, 495-527. 
[19] Beltrão, N.E.M. and Azevedo, D.M.P. (1993) Defasagem entre as produtividades real e potencial no algodoeiro herbáceo: Limitações morfológicas e ambientais (The Gap between Actual and Potential Productivity in the Cotton Plant Herbaceous: Morphological and Environmental Limitations). Embrapa, Campina Grande.

[20] Soares, J.J., Jácome, A.G., Sousa, J.G., Oliveira, R.H. and Wanderley, D.S. (1997) Influência do desfolhamento simulados pelo ataque do curuquerê no desenvolvimento vegetativo e no rendimento do algodoeiro (Influence of Defoliate Simulated by Attack of Cotton Leafworm on Vegetative Development and Yield of Cotton Plant). Embrapa, Campina Grande. 